\title{
UNDERGROUND COAL GASIFICATION: A REGULATORY FRAMEWORK FOR ALBERTA
}

\author{
ASTRID KALKBRENNER *
}

Underground Coal Gasification (UCG) is a new emerging clean coal technology. It holds promise for reaching and making use of very deep coal seams that technically could not otherwise have been mined at these depths. UCG technology and knowledge developed significantly during the 20th century. Countries around the world with large coal deposits sustain and promote UCG research and launch projects with the intention to commercially deploy UCG. Alberta currently hosts two UCG projects, and a third project is under consideration. The development of these projects suggested the need for a UCG specific regulatory approval process. In 2011, Alberta enacted specific UCG legislation. This article deals with recent developments in UCG technology and its regulations. The aim of this article is to present Alberta's current UCG regulatory framework as a model for other jurisdictions.

\begin{abstract}
La gazéification in situ est une nouvelle technologie du charbon propre émergente. Elle promet d'atteindre et d'utiliser des filons de charbon très profonds dont l'extraction ne serait autrement pas techniquement possible à ces profondeurs. Les connaissances spécialisées et ces nouvelles technologies se sont beaucoup développées dans le courant du $20^{e}$ siècle. Partout dans le monde, des pays ayant d'importants gisements houillers soutiennent et favorisent la recherche dans ce domaine et lancent des projets avec l'intention d'utiliser la gazéification in situ sur le plan commercial. À l'heure actuelle, l'Alberta compte deux projets de gazéification in situ et un troisième projet est à l'étude. Le développement de ces projets laisse entendre un besoin pour un système d'approbation réglementaire spécifique pour la gazéification in situ. En 2011, l'Alberta a adopté une loi spécifique à ce sujet. Le présent article traite des derniers développements dans la technologie et la réglementation en la matière. Le but de cet article consiste à présenter le cadre de réglementation actuel à l'égard de la gazéification in situ en Alberta comme modèle pour d'autres juridictions.
\end{abstract}

\section{TABLE OF CONTENTS}

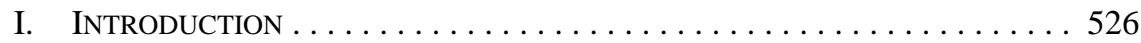

II. WhAT IS UNDERGROUND COAL GASIFICATION? . . . . . . . . . . . . . . 530

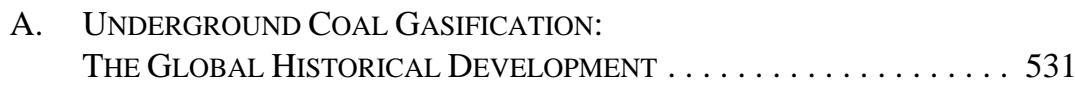

B. UNDERGROUND COAL GASIFICATION

PROJECTS In Alberta . . . . . . . . . . . . . . . . . . 532

C. SELECTED ISSUES, RISKS, AND BARRIERS

of UndeRgRound CoAL GASIFICATION . . . . . . . . . . . . . . 534

D. COnCLUSION ............................ 540

III. CoAl AND PROPERTy Rights in ALBERTA . . . . . . . . . . . . . . . . . 541

A. Property Rights in LANd and Minerals ............ 541

B. ACCESS to the SuRface: THE SURFACE RightS ACT ....... 542

Ms Kalkbrenner (LLM, Calgary) is a PhD Candidate at the Law Faculty of the University of Calgary. She can be contacted via email at akalkbre@ucalgary.ca. This article considers the literature and legal changes in the regulatory framework until 10 June 2013, the date of submission. The author wishes to thank Professor Nigel Bankes, Faculty of Law, University of Calgary, for his valuable comments on earlier drafts and the two anonymous referees for providing useful feedback on this article. This article is supported by a grant from Carbon Management Canada. 
IV. UNDERGROUND COAL GASIFICATION:

THe Regulatory Framework in Alberta . . . . . . . . . . . . . . . . . . 543

A. LEGISLATIVE DEVELOPMENT FOR

UNDERGROUND COAL GASIFICATION IN ALBERTA . . . . . . . . . . 543

B. THE “OlD” REgime: REgUlatORY APPROVAlS

FOR THE SWAN HiLls AND LAURUS PROJECTS . . . . . . . . . . . . . . . 544

C. THE CURRENT REgUlATORY FRAMEWORK FOR

UndERGROUND COAL GASIFICATION IN ALBERTA . . . . . . . . . . 545

D. APPLICATION REQUIREMENTS . . . . . . . . . . . . . . . . . . . 546

E. LIABILITY FOR UNDERGROUND COAL GASIFICATION

ACTIVITIES UNDER ALBERTA LAW . . . . . . . . . . . . . . 549

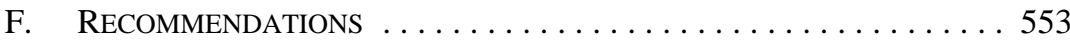

V. CONCLUSION . . . . . . . . . . . . . . . . . . . . . . . . . . . . . . . 554

\section{INTRODUCTION}

The word "coal” carries different associations. For some, it offers a secure and stable source of energy, but for others coal is "dirty" and an important contributor to carbon dioxide $\left(\mathrm{CO}_{2}\right)$ emissions and global warming. Still others prefer to refer to clean coal (technologies). Clean coal technologies ${ }^{1}$ (CCTs) aim to make use of (dirty) coal in an environmentallyfriendly, sustainable way. CCTs aim to bridge between coal, as a cheap and abundant fossil fuel and as a potentially clean source of energy for a world in which demand for energy is increasing. CCTs do not eliminate harmful emissions ${ }^{2}$ but they do have the potential to mitigate the $\mathrm{CO}_{2}$ emissions associated with using coal. Clean coal sounds promising — but can it become a reality? ${ }^{3}$

Global primary energy is growing. The International Energy Agency (IEA) predicts a 35 percent increase in demand between 2010 and 2035. ${ }^{4}$ Electricity demand increased by 40 percent between 2000 and 2010 and is predicted to further increase by 70 percent between 2010 and $2035 .{ }^{5}$ Fossil fuels continue to be the prevalent primary energy source. In 2010,

Clean coal technologies (CCTs) aim at reducing the environmental impact of using coal. In the past, the focus was on reducing emissions of particulates, $\mathrm{SO}_{2}, \mathrm{NO}_{x}$, and mercury. Now, the focus is on low and near-zero greenhouse gas emissions through technologies, such as carbon capture and storage (CCS). According to the International Energy Agency (IEA), CCTs are grouped into five categories: (1) coal upgrading technology; (2) efficiency improvements at existing power plants; (3) advanced technologies and near zero-technologies; (5) $\mathrm{CO}_{2}$ transport and storage technologies (Coal Industry Advisory Board \& IEA, Clean Coal Technologies: Accelerating Commercial and Policy Drivers for Deployment (Paris: International Energy Agency, 2008) at 9). Examples of CCTs are: fluidized-bed combustion, integrated gasification combined cycle, flue gas desulfurization, low nitrogen oxide burners, high-efficiency fuel cells, advanced high-efficiency combustion, and CCS (National Mining Association (NMA), Clean Coal Technology, online: NMA < http://www.nma.org/pdf/fact_sheets/cct.pdf>).

2 "[T]he burning of coal for power generation has been proven to be one of the principal causes of anthropogenic climate change and global warming” (Energy Resources Conservation Board (ERCB), Review of Underground Coal Gasification with Reference to Alberta's Potential (ERCB/AGS 2009) at 13, online: Alberta Geological Survey <http://www.ags.gov.ab.ca/publications/OFR/PDF/OFR_2009_ 10.PDF $>$ [ERCB-AGS]). Coal combustion produces $\mathrm{CO}_{2}$, methane, particulates and oxides of nitrogen, oxides of sulfur, mercury, and various carcinogenic chemicals and heavy metals (Paul R Epstein et al, "Full Cost Accounting for the Life Cycle of Coal” (2011) 1219 Annals of the New York Academy of Sciences 73 at 85$)$.

The answer to this question also depends on what exactly is considered as being clean: How clean is clean?

$4 \quad$ International Energy Agency (IEA), World Energy Outlook 2012 (Paris: IEA, 2012) at 50 [WEO 2012]. Ibid at 180 . 
fossil fuel's share of the energy mix was 81 percent and is expected to be in the range of 63 percent to 80 percent through $2035 .^{6}$

Coal's share of global primary energy use was 30 percent in $2010 .^{7}$ The IEA estimates that world demand for coal will grow by 30 percent of the global energy market by $2035 .{ }^{8}$ Coal accounted for over 40 percent of electricity output in $2010 .{ }^{9}$ Coal is the world's most abundant fossil fuel, with proven reserves of 1,004 gigatonnes (Gt), equivalent to 140 years of current global coal production. ${ }^{10}$ As a result, coal could provide a secure source of energy for hundreds of years.

The use of coal is controversial. On the one hand, there is a demand for cheap and abundant energy, but, on the other hand, there is a demand in our carbon-constrained world to reduce the $\mathrm{CO}_{2}$ emissions resulting from energy production. Coal may be abundant and broadly distributed, but it is an especially damaging fossil fuel from a climate and environmental perspective. Coal combustion caused 43 percent of global $\mathrm{CO}_{2}$ emissions in 2009 compared with 37 percent of such emissions from oil and 20 percent from gas combustion. ${ }^{11}$ Coal combustion produces the highest $\mathrm{CO}_{2}$ emissions when compared with the other fossil fuels and therefore has the greatest potential to increase global warming. ${ }^{12}$

However, coal is a reliable energy source and the technology for extracting and using coal is well understood. On average, the energy production costs from coal are less than other energy sources. ${ }^{13}$ Furthermore, coal is globally widely distributed, including in many developing countries. ${ }^{14}$ CCTs promise the possibility that we will be able to continue to use coal as a cheap and stable energy supply, even in a de-carbonizing world.

One such CCT is underground coal gasification. Underground coal gasification (UCG) technology was first developed in the late 19th century but has re-emerged as a promising method to utilize inaccessible coal reserves in a cleaner manner than other coal combustion

$6 \quad$ Ibid at 51.

Federal Institute for Geosciences and Natural Resources (BGR), Reserves, Resources and Availability of Engery Resources - Annual Report 2011 (Hannover: German Mineral Resources Agency and Federal Institute for Geoscience and Natural Resources, 2012) at 24 [BGR]. In 2010, the global coal demand was at 4,963 million tonnes of coal equivalent (Mtce) and is predicted to increase to 7,889 Mtce in 2035. This would dethrone oil as a leading primary energy fuel in 2025 (WEO 2012, supra note 4 at 156-57). The abbreviation for “million tonnes of coal equivalent” (Mtce), is used when comparing different fuels. One Mtce of any other fuel gives the same heat when burnt as one million tonnes of coal. 1 Mtce equals 0.7 million tonnes of oil equivalent (Mtoe) (WEO 2012, ibid at 641).

$9 \quad$ IEA, World Energy Outlook 2011 (Paris: IEA, 2011) at 354 [WEO 2011]. A reference to previous editions of the WEO such as the 2011 and 2010 is appropriate because they differ in their focus. The WEO 2012, ibid at 163, makes a reference to the WEO 2011 for a detailed assessment of coal resources, etc.

$10 \quad$ BGR, supra note 7 at 14, 25; WEO 2012, ibid at 163.

11 IEA, IEA Statistics: $\mathrm{CO}_{2}$ Emissions from Fuel Combustion (Paris: IEA, 2011) at 8.

$12 \quad$ Heather Yundt, "Coal represents largest threat to climate: experts," Calgary Herald (21 February 2012) A3. For electricity generation the lifecycle $\mathrm{CO}_{2}$ emission estimates, among fossil fuels measured in $\mathrm{gCO}_{2} \mathrm{e} / \mathrm{kWh}$, are: nuclear 66, natural gas 443, diesel and heavy oil 778, coal 960 to 1050 (Benjamin K Sovacool, "Valuing the Greenhouse Gas Emissions from Nuclear Power: A Critical Survey” (2008) 36 Energy Policy 2940 at 2950).

13 The market price of coal fluctuates and varies significantly across countries and regions (WEO 2011, supra note 9 at 65, 361-62).

14 WEO 2011, ibid. 
methods. ${ }^{15}$ Most countries with major coal reserves are currently conducting research in this field to promote commercial use and deployment. UCG is attractive for other reasons as well since it offers the opportunity to use coal seams that are not minable using conventional mining methods because of the depth, ${ }^{16}$ quality, surface or social constraints, and remoteness from markets or transport. ${ }^{17}$ Other advantages of UCG as opposed to surface mining are, inter alia, lower capital investment costs, no human labour underground, and minimum surface disruption. It is even possible that pore space vacated by these operations may be used for the storage or disposal element of a carbon capture and storage (CCS) scheme.

The IEA World Energy Outlook (WEO) 2010 recognised the potential of UCG to recover coal deposits that were assessed as being un-minable with conventional techniques. ${ }^{18}$ Nevertheless, UCG does present challenges, inter alia, groundwater contamination and subsidence. There is little known about the effects of UCG on the surrounding geology and hydrogeology. Also, the proprietary nature of the applied technology in this field makes it difficult to evaluate. ${ }^{19}$ Currently there is limited experience with UCG because only 15 to 20 million tonnes of coal have been gasified with UCG technology. ${ }^{20}$ The WEO recommends that "UCG project developers need to consider how to move quickly from pilot projects at carefully chosen and favourable sites to more ambitious demonstration projects that can provide the design basis for large commercial projects in a wide range of coal types and situations."21

At the international level, Canada is not known for having significant recognized coal reserves. However, UCG might change this since the technology makes deep coal deposits usable. Within Canada, the province of Alberta has the largest coal reserves. The Alberta Energy Regulator (AER), the former Energy Resources Conservation Board ${ }^{22}$ (ERCB), estimates Alberta's remaining established coal reserves to be about $33.3 \mathrm{Gt}$ (31 December 2012) which includes all types of coal. ${ }^{23}$ Of that, $22.7 \mathrm{Gt}$ (68 percent) is considered to be recoverable by underground mining methods, and $10.4 \mathrm{Gt}$ recoverable by surface mining.

S Julio Friedmann, Ravi Upadhye \& Fung-Ming Kong, "Prospects for Underground Coal Gasification in Carbon-Constrained World” (2009) 1 Energy Procedia 4551 at 4551.

Deeper coal seams show various advantages compared with shallower coal seams "in terms of cavity growth, power output and environmental benefits, and the possibility of maintaining supercritical conditions for $\mathrm{CO}_{2}$ sequestration” (Elizabeth Burton, Julio Friedmann \& Ravi Upadhye, Best Practices in Underground Coal Gasification (California: Lawrence Livermore National Laboratory, 2004) at 50). Marc-André Schulten, Modellierung verschiedener Szenarien zur Teerentstehung im Rahmen der Untertagevergasung von Steinkohle [Modeling various Scenarios for the Formation of Tar during the Process of Underground Gasification of Hard Coal] (Master Thesis, Rheinisch Westfälische Technische Hochschule Aachen, 2010) at 21 [unpublished] [translation by author]; RJ Richardson, Alberta's 2 Trillion Tonnes of 'Unrecognized' Coal: Client Report to: Alberta Innovates Energy and Environment Solutions (Edmonton: Alberta Innovates Energy and Environment Solutions, 2010) at 18.

International Energy Agency, World Energy Outlook 2010 (Paris: International Energy Agency, 2010) at 205 [WEO 2010].

$\epsilon \mathrm{UCG}$ is a proprietary process employed by Ergo Exergy and because of that not much has been published on it (Burton, Friedmann \& Upadhye, supra note 16 at 51-52).

WEO 2010, supra note 18 at 206.

Ibid.

The Energy Resources Conservation Board (ERCB) was dissolved with the coming into effect of the Responsible Energy Development Act (SA 2012 cR-17.3) [REDA]. The new energy regulator is the Alberta Energy Regulator (AER). For more information see below at IV.A-C. This article uses both names (AER and ERCB), depending on when the document or approval was issued.

23 Energy Resources Conservation Board (ERCB), Alberta's Energy Reserves 2012 and Supply/Demand Outlook 2013-2022, ST98-2013 (Calgary: ERCB 2013) at 8-1 [ERCB, Outlook 2013]; Richardson, supra note 17 at 5 . 
This represents more than twice the energy of all the province's other conventional nonrenewable energy resources, such as oil, oil sands, and gas. ${ }^{24}$

Moreover, the AER considers Alberta a prime candidate for UCG because of the province's coal quality and quantity. ${ }^{25}$ Alberta has deep coal resources and assessments by the Alberta Geological Survey have identified three major coal deposits (the Ardley, Horseshoe Canyon, and upper Mannville coal zones) as viable candidate locations to develop commercial UCG projects. ${ }^{26}$ Over the years, improved horizontal drilling technologies and various test projects have demonstrated and developed the technical, economic, and environmental benefits resulting from UCG. Alberta's significant UCG potential is based on the following factors:

- $\quad$ Deep, thick coal seams;

- $\quad$ Support for energy innovation;

- $\quad$ Proximity to oil development provides opportunity to sell $\mathrm{CO}_{2}$ for enhanced oil recovery (EOR);

- $\quad \mathrm{CO}_{2}$ sequestration opportunities;

- $\quad$ Access to energy transmission infrastructure and markets;

- $\quad$ Experienced well-drilling service providers; and

- $\quad$ Provincial and industry initiatives to produce clean energy. ${ }^{27}$

The UCG industry has already shown interest in Alberta's coal. The AER approved two applications for UCG projects, which led the Alberta legislature, in 2011, to adopt a tailormade regulatory framework for UCG activities. ${ }^{28}$ However, current low natural gas prices (CAD\$3 per gigajoule (GJ)) caused one Alberta UCG operator to defer its UCG project until gas prices stabilize at CAD\$5/GJ. ${ }^{29}$

Government of Alberta, “Talk about Coal: Facts on Coal” (February 2010) at 1, online: <http://www. energy.alberta.ca/coal/pdfs/FactSheet_CoalFacts.pdf> [Coal factsheet].

ERCB, Proposed Legislative Framework for In Situ Coal Development (Calgary: ERCB, 2009) at iii [ERCB 2009].

ERCB-AGS, supra note 2 at 49.

Swan Hills Synfuels, “Alberta: The Natural Choice for UCG,” online: <http://www.swanhills-synfuels. com/iscg/alberta/>.

The two UCG projects are Swan Hills (application in 2007 and approved in 2008) and Laurus (application in 2009 and approved in 2011). None of these projects are currently operating. For Swan Hills see, online: <http://swanhills-synfuels.com/projects/overview/>. For Laurus see, online: AER, "Index of AER Orders and Approvals" (January 2014), online: AER < http://www.aer.ca/documents/ rders/ibo/IBO_Part_O.PDF>.

"Swan Hills Synfuels, Alberta Government Cancel Carbon Capture and Storage Project” The Huffington Post (25 February 2013), online: <http://www.huffingtonpost.ca/2013/02/25/swan-hills-synfuels-albertacarbon-capture_n_2759771.html>; Karen Kleiss \& Marty Klinkenberg, "Swan Hills Synfuels defers carbon capture project because of low natural gas prices,” Edmonton Journal (25 February 2013), online: Edmonton Journal <http://www.edmontonjournal.com/technology/Swan+Hills+Synfuels+ defers+carbon+capture+project+because+natural+prices/8012978/story.html $>$. 
This article focuses on the current regulatory framework for UCG in Alberta and its development. The first part identifies gaps and problems in the current regime which must be addressed by legislation. The second part of this article gives an overview of UCG technology. It presents a brief history of the development of UCG and projects around the world and a more detailed description of proposed UCG projects in Alberta. Then, it describes selected issues associated with UCG, such as site selection, water impacts, and subsidence. Part three explains the property rights system for land and minerals (including coal), as well as surface access issues in Alberta. The fourth part deals with the development of the regulatory framework for UCG projects and liability issues associated with UCG. Part four ends with recommendations for improving the regulatory framework. The fifth part concludes.

\section{WHAT IS UNDERGROUND COAL GASIFICATION?}

Two different terms are used to describe the same process: in situ coal gasification and underground coal gasification. UCG is the more frequently used term in the technical and international literature. The Alberta legislature decided to use the term in situ coal gasification (ISCG), but this article uses the more common term UCG.

UCG is different from coal gasification. Coal gasification takes place on the surface and requires special plants, large coal storage facilities, and gasifiers. ${ }^{30}$ UCG converts coal underground (in situ) into synthesis gas or syngas, also called "product gas.” In order to extract the syngas, injection and production wells are drilled from the surface into the coal seam. The wells are linked together with methods such as reversed combustion, ${ }^{31}$ explosive fracturing, ${ }^{32}$ hydro-fracturing, ${ }^{33}$ or directional drilling. ${ }^{34}$ Catalysts are then injected into the injection well. ${ }^{35}$ Different catalysts are used depending on the required quality of the syngas. Preferred catalysts are air, oxygen, $\mathrm{CO}_{2}$, water steam, hydrogen $\left(\mathrm{H}_{2}\right)$, or a mixture of possible catalysts. ${ }^{36}$ The coal is then ignited in a controlled manner. The produced gas is a mixture of carbon monoxide (CO), $\mathrm{H}_{2}$, methane $\left(\mathrm{CH}_{4}\right), \mathrm{CO}_{2}$, and other constituents which flow to the surface via one or more production wells. ${ }^{37}$ Depending on the composition and quality of the syngas, it may be used for a variety of applications, such as generation of electricity and the production of liquid hydrocarbon fuels, natural gas surrogates, and valuable chemical

Evgeny Shafirovich \& Arvind Varma, "Underground Coal Gasification: A Brief Review of Current Status” (2009) 48 Industrial \& Engineering Chemistry Research 7865 at 7865.

31 For an explanation of the term see e.g. Schlumberger, “Oilfield Glossary 'reversed combustion,"” online: $<$ http://www.glossary.oilfield.slb.com/en/Terms/r/reverse_combustion.aspx>.

32 Explosive fracturing, "also known as well shooting, detonated an explosive within the well to break the reservoir rocks.... [E]xplosive fracturing introduced liquid nitrogen into the well via a tin cylinder referred to as a torpedo. The torpedo was lowered into the wellbore and detonated. The explosion created a huge hole that was then cleaned out and completed as an openhole, leaving the bottom of the well open into the reservoir” (Rigzone, “How Does Well Fracturing Work to Stimulate Production?,” online: $<$ http://www.rigzone.com/training/insight.asp?insight_id=319\&c_id=4>).

33 " $[\mathrm{H}]$ ydraulic fracturing, also known as a frac job, is the practice of injecting a well with large amounts of frac fluids under high pressure in order to break the rocks. Performed on both openhole and casedwell perforations, hydraulic fracturing quickly replaced explosive fracturing” (ibid).

34 For an explanation of the term, see e.g. Schlumberger, “Oilfield Glossary 'directional drilling,”, online: <http://www.glossary.oilfield.slb.com/en/Terms.aspx?LookIn=term\%20name\&filter=directional\%20 drilling>.

35 Burton, Friedmann \& Upadhye, supra note 16 at 49.

36 DW Gregg \& TF Edgar, “Underground Coal Gasification” (1978) 24:5 The American Institute of Chemical Engineers 753 at 754; Schulten, supra note 17 at 11.

Gregg \& Edgar, ibid at 754. 
products. ${ }^{38}$ It must first be cleaned before it can be further used. The main impurities are particulates, tars, sulfur compounds (such as hydrogen sulfide $\left(\mathrm{H}_{2} \mathrm{~S}\right) /$ carbonyl sulfide (COS)), mercury, arsenic, and lead. ${ }^{39} \mathrm{CO}_{2}$ must also be removed from the syngas and can be used for industrial purposes, such as EOR, or can be vented or disposed of through a CCS project.

\section{A. UNDERGROUND COAL GASIFICATION: THE GLOBAL HISTORICAL DEVELOPMENT}

All countries with significant coal reserves have considered and are currently promoting trials and research in UCG as an alternative for generating energy. ${ }^{40}$ For most projects, the technical, financial, and environmental difficulties have proven to be deterrents to the longterm and large-scale deployment of UCG technology. ${ }^{41}$

UCG technology was first developed in Europe and Russia at the end of the 19th century. ${ }^{42}$ Russia was the first to develop a strong national program in UCG research and development and thus achieved successful commercial production at numerous sites. ${ }^{43}$ Today, only one facility in Angren in Uzbekistan is still operating. ${ }^{44}$ Following the energy crisis in 1973, Western Europe and the United States initiated research programs in the area of UCG. England, France, Belgium, and Spain conducted trials in deeper coal seams (600 to 1200 metres). ${ }^{45}$ In the 1970 s and 1980 s, the US started a series of trials. ${ }^{46}$

Today, there are other major UCG projects taking place worldwide. The UCG Chinchilla facility in Queensland, Australia, which operated between 1999 and 2003, gasified around 35,000 tonnes of coal, and obtained equivalent heat values of 4.5 to 5.7 megajoule per metre cubed $\left(\mathrm{MJ} / \mathrm{m}^{3}\right) .{ }^{47}$ The entire UCG cycle in Chinchilla produced 25 percent less $\mathrm{CO}_{2}$ when compared to a conventional coal fired power plant. ${ }^{48}$ In Mpumalanga, South Africa, the Majuba UCG facility started operations in 2007. Majuba is producing syngas that is used for

$38 \quad$ Shafirovich \& Varma, supra note 30 at 7865.

Burton, Friedmann \& Upadhye, supra note 16 at 55.

Schulten, supra note 17 at 32.

Ibid at 32.

For the historical development of UCG see Alexander Y Klimenko, "Early Ideas in Underground Coal Gasification and Their Evolution” (2009) 2 Energies 456 at 462; Gregg \& Edgar, supra note 36 at 754; Burton, Friedmann \& Upadhye, supra note 16 at 20; Schulten, ibid at 21.

43 For detailed information on the Russian trials see DR Stephens, RW Hill \& IY Borg, "Underground Coal Gasification Review" (Paper delivered at the 18th Annual Oil Shale Symposium and the Western Synfuels Symposium, Grand Junction, CO, 24-26 April 1985), Lawrence Livermore National Laboratory UCRL-92068 at 4-6; Burton, Friedmann \& Upadhye, ibid at 42-47; Gregg \& Edgar, ibid at 756-69; Klimenko, ibid at 464-71.

$44 \quad$ Schulten, supra note 17 at 35 . The facility generates 3.5 to $4 \mathrm{~m}^{3}$ gas per $\mathrm{kg}$ of coal with an equivalent heat value of $4 \mathrm{MJ} / \mathrm{m}^{3}$. The synthesis gas is transported 3.5 kilometres via a pipeline to a power plant where the gas is used to fire three $50 \mathrm{MW}$ power station boilers (ibid).

45 For detailed descriptions of the European UCG trials see Burton, Friedmann \& Upadhye, supra note 16 at 37, 38; Schulten, ibid at 21.

46 Hanna, Wyoming (1973-1979); Hoe Creek, Wyoming (1976-1979); Colony, Tennessee (1978-1979); Princetown, West Virginia (1979); Rawlins, Wyoming (1979-1981); Centralia, Washington (19811983); and Rocky Mountain, Wyoming (1986-1988). For detailed descriptions of the US UCG trials see Stephens, Hill \& Borg, supra note 43 at 6-8; Burton, Friedmann \& Upadhye, ibid at 31-37; Schulten, ibid at 21-22, 36-38.

$47 \quad$ Schulten, ibid at 22.

48 Burton, Friedmann \& Upadhye, supra note 16 at 39-41; Schulten, ibid at 39. 
power generation in an existing 4.2 gigawatt (GW) coal-fired power plant. ${ }^{49}$ Majuba is the biggest and most complex UCG facility worldwide.

Additional projects are taking place or are planned in China, India, Canada, and New Zealand. ${ }^{50}$ China has carried out several large-scale UCG studies since 1984 with nine UCG field tests using the gas products for combustion and power generation. ${ }^{51}$

\section{B. Underground Coal Gasification Projects in Alberta}

The focus of this article is the regulatory framework of Alberta. Therefore, the next section provides an overview of two major UCG projects, Swan Hills and Laurus, both of which have recently received regulatory approval. A third company, Nordic Oil and Gas Ltd., is currently in the early stages of formulating a UCG project. ${ }^{52}$

\section{SWAN HiLls Synfuels/SAgitawah Power ProJECT}

Swan Hills Synfuels Ltd. filed an application with the then-called Alberta Energy and Utilities Board in 2007 for approval to construct, operate, and reclaim an experimental in situ coal gasification scheme. ${ }^{53}$ The project is located 17 kilometres southwest of Swan Hills on Crown-owned land. Swan Hills Synfuels Ltd. acquired the Crown-owned mineral rights ${ }^{54}$ under the Mines and Minerals Act. ${ }^{55}$ Swan Hills Synfuels Ltd. will use the Controlled Retraction Injection Point ${ }^{56}$ (CRIP) ISCG technology. ${ }^{57}$ "The project will use ISCG [UCG]

According to Ergo Exergy, the

pilot plant will provide for an initial generating capacity of approximately 6 MWe, which is sufficient to co fire a single burner at Majuba power station. Pending on success of the pilot program, gas production will be scaled up to eventually provide $30 \%$ of the plant's fuel. At that stage, the $\in$ UCG facility will produce over 100 PJ per annum to generate approximately 1,200 MWe of electricity.

Ergo Exergy, Majuba, South Africa - Eskom, online: <http://www.ergoexergy.com/about_us_ourb_ projects_eskom.htm>.

Burton, Friedmann \& Upadhye, supra note 16 at 38-41; Schulten, supra note 17 at 22.

Liu Shu-qin et al, “Groundwater Pollution from Underground Coal Gasification” (2007) 17:4 J China U Mining \& Tech 467 at 468.

The Winnipeg-based junior oil and gas company plans to drill four to six stratigraphic test wells to test the lower Horseshoe Canyon coals in order to determine their suitability for an UCG project. The company acquired 3,856 hectares ( 9,528 acres) of coal leases northwest of Drumheller with an estimated recoverable coal deposit of 54 million tonnes. So far, Nordic Oil and Gas Ltd. has yet to file a UCG related application (Nordic Oil and Gas, online: <http://www.nordicoilandgas.com/>).

Swan Hills project application no 1517784, dated 3 July 2007; approved under no 11175 on 5 June 2008. The application was revised twice (application no 1615737 and no 1656306) and the approval altered twice accordingly (approval no 11175A and no 11175B). The experimental scheme approval will expire on 30 April 2013. Swan Hills Synfuels has to apply for and obtain approval if it wants to continue the project after the expiry date. ERCB, Approval No 11175 at 11 [Swan Hills project application]. See Swan Hill project application, ibid at 1, 6 .

Mines and Mineral Act, RSA 2000, c M-17 [MMA]. Under section 9 of the MMA, Synergia, the parent company of Swan Hills Synfuels, concluded an agreement with Her Majesty the Queen in Right of the Province of Alberta, inter alia, with respect to the granting of the rights to all coal in the project area. Swan Hills project application, ibid at 6 .

The literature uses the terms "controlled retraction injection point” and "continuous retraction injection point process” interchangeably. According to Kempka et al, CRIP is the only industrial-scale technique that is suitable for the gasification of deep-lying coals seams (Thomas Kempka et al, "Economic Viability of In-Situ Coal Gasification with Downstream $\mathrm{CO}_{2}$ Storage” (2009) 1 Glückauf Mining Reporter 43 at 45$)$ :

In the CRIP process, the production well is drilled vertically, and the injection well is drilled using directional drilling techniques so as to connect to the production well.... Once the channel is established, a gasification cavity is initiated at the end of the injection well in the horizontal section of the coal seam. Once the coal near the cavity is used up, the injection point is retracted (preferably by burning a section of the liner) and a new gasification cavity is initiated. In this 
to tap deep, unmineable coal to produce syngas that will be processed in a conventional gas plant to remove $\mathrm{CO}_{2}$ as a byproduct stream. The syngas will then be pipelined to a combined cycle ${ }^{58}$ power generation station to produce low emissions electricity." ${ }^{59}$ The project proposes to use only saline water in the gasification process. ${ }^{60}$

The targeted coal seams are located 1,400 metres (4,600 feet) below the surface. ${ }^{61}$ It is envisioned that the syngas produced will generate 300 megawatts (MW) of power, which would supply 300,000 homes with energy. The proponent anticipates capturing about 1.3 million tonnes of $\mathrm{CO}_{2}$ per year and selling it to EOR customers in the Swan Hills area. ${ }^{62}$ The construction of the project was envisioned for 2013 with CCS beginning by the end of 2015 .

The Province promised the project a CAD $\$ 285$ million grant as part of the Province's CAD\$2 billion CCS funding program. ${ }^{63}$ However, in February 2013, the proponent withdrew on the grounds of low natural gas prices which made the project economically infeasible and as a result the Province cancelled the promised funding. ${ }^{64}$ Swan Hills Synfuels Ltd. has stressed that the project is only deferred and will come forward again when natural gas prices increase from the current CAD\$3 per GJ (May 2013) and stabilize at around CAD\$5 per GJ. ${ }^{65}$

\section{LAURUS ENERGY CANADA INC: PARKLAND COUNTY (DRAYTON VALLEY, AB)}

Laurus Energy Canada Inc. (Laurus) filed an application for approval of its proposed Experimental Underground Coal Gasification Project (Demonstration Project) with the

manner, a precise control over the progress of gasification is obtained. The CRIP process retracts the combined steam and oxygen injection point to control the location of the combustion front. The syngas ... is brought to the surface and processed to remove particulates, $\mathrm{CO}_{2}$ and $\mathrm{H}_{2} \mathrm{~S}$ and to convert the $\mathrm{CO}, \mathrm{CH}_{4}$ and higher hydrocarbons to more hydrogen.

Burton, Friedmann \& Upadhye, supra note 16 at 51.

Swan Hills project application, supra note 53 at 3.

Combined cycle power generation combines "two thermal cycles in one plant, and when two cycles are combined in a single power plant, the efficiency that can be achieved is higher than that of one cycle alone. Thermal cycles with the same or with different working media can be combined; however, a combination of cycles with different working media is more interesting because their advantages can complement one another.... The combination most widely used today for commercial power generation is that of a gas topping cycle with a water/steam bottoming cycle" (Rolf Kehlhofer et al, CombinedCycle Gas Steam Turbine Power Plants, 3rd ed (Tulsa: PennWell, 2009) at 1, 2). The process works as follows: "Coal or other fuel is gasified in a gasification chamber and the resultant syngas is used to generate electricity. The syngas is first combusted in a gas turbine and the waste heat is used to heat water to turn a steam turbine. The rotary motion from each turbine is used to generate electricity" (Jeremy Moorhouse, Marc Huot \& Matt McCulloch, Underground Coal Gasification: Environmental Risks and Benefits (Drayton Valley: The Pembina Institute, 2010) at 22). Swan Hills ISCG/Sagitawah Power Project, "Tapping into Coal," online: Swan Hills Synfuels <http:// www.swanhills-synfuels.com/wp-content/media/Nitrogen+Syngas-tapping_into_coal.pdf $>$. Swan Hills project application, supra note 53 at 4, 8. See also online: Swan Hills Synfuels $<$ http://swan hills-synfuels.com/projects/demonstration-project/>.

61 Swan Hills project application, ibid at 1.

62 Government of Alberta News Release, "Clean Energy Project Agreement in Place” (27 July 2011) online: Swan Hills Synfuels <http://www.swanhills-synfuels.com/wp-content/media/ABGov-NewsRelease-July-27-2011.pdf> [Gov AB News Release 27 July 2011]. Oil and Gas Journal <http://www.ogj.com/articles/2013/02/alberta--swan-hills-synfuels-end-ccs-pact. html>.

65 Kleiss \& Klinkenberg, supra note 29. 
ERCB and Alberta Environment in 2009. ${ }^{66}$ Laurus uses and holds licences to the proprietary Exergy UCG TechnologyTM provided by Ergo Exergy Technologies, Inc. ${ }^{67}$ Laurus identified the Drayton Valley area in Alberta as having great potential for UCG technology. Laurus has negotiated the option to purchase surface land, which is privately-owned. ${ }^{68}$ The mineral rights are owned by the Crown. Laurus holds coal leases covering 72 sections of land (in total 19,200 hectares). ${ }^{69}$ The Demonstration Project comprises the construction, operation and reclamation of an experimental gas recovery scheme located about 15 kilometres northeast of Drayton Valley. ${ }^{70}$ The required project facilities will occupy an area of approximately 2.55 hectares. $^{71}$ The project aims to produce up to 70,120 standard cubic metres per day $\left(\mathrm{Sm}^{3} / \mathrm{d}\right)$ syngas $^{72}$ The start-up is scheduled for 2013 and the commercial facility is planned to run for 30 years with the aim of producing $300 \mathrm{MW}$ of electricity.

\section{SELECTED ISSUES, RISKS, AND BARRIERS OF UNDERGROUND COAL GASIFICATION}

If UCG technology is to be commercially deployed at large scales the technology needs to address important issues, particularly site selection and impacts on the environment, such as subsidence and water impacts. Both issues also need to be addressed in the regulatory framework.

\section{Site SELECTION CRITERIA}

As with other activities, such as oil and gas drilling, nuclear facilities and CCS, site selection criteria are also crucial for UCG projects. The selection criteria differ from those applied to underground mining, especially with regard to the requirements for depth and thickness of coal seams. ${ }^{73}$ Important site selection factors are: (1) the depth of the coal seam; (2) the porosity and permeability of the coal seam; (3) the proximity to aquifers; and (4) the thickness of the coal seam.

Recommendations vary with respect to the thickness of coal seams. Generally, thicker seams require fewer wells. This reduces drilling costs and implies less surface impacts. Scientific opinions about the range of an optimal thickness vary between 10 metres and 0.5 metres. However, scientists recommend that the coal thickness should not be less than 2 metres because seams less than 2 metres results in a considerable heat loss that leads to low thermal efficiency and lower product gas quality. ${ }^{74}$

The following information is based on the project application by Laurus, dated 22 September 2009 [Laurus project application], on file with the author.

See Laurus project application, ibid at 1-1, 1-4.

Ibid at 1-4, 1-5.

Ibid at 1-4.

The project is situated in Parkland County on land currently used as residential land and cultivated farmland. The Demonstration Project is close to existing infrastructure, such as roads, gas pipelines, and power lines (Laurus project application, ibid at 1-1).

Ibid at 1-5.

The gasification process will use around 2300 tonnes of coal annually and will require dewatering about $18,500 \mathrm{~m}^{3}$ of groundwater per year (Energy Resources Conservation Board (ERCB), “Application 1625048: Amended Notice of Application Laurus Energy Canada Inc. Experimental Underground Coal Gasification Project Parkland County” (18 August 2010), online: AER <http://www.aer.ca/rss/ application-1625048\#> [ERCB - Laurus Notice]).

Shafirovich \& Varma, supra note 30 at 7872-73.

Burton, Friedmann \& Upadhye, supra note 16 at 53; Shafirovich \& Varma, ibid at 7873. 
Experts suggest a minimum depth of 12 metres $^{75}$ but preferably deeper than 200 metres in order to decrease the subsidence risks. ${ }^{76}$ Depths of more than 300 metres are more technically challenging in terms of drilling technology, but operations at these depths minimize subsidence risks. Generally, the deeper the extraction depth, the lower the probability of surface subsidence. The higher gasification pressure at this depth yields a higher methane content and thus increases the heating value of the produced gas. Another advantage of deeper coal seams is that they are less likely to be hydrologically linked with potable aquifers thus minimizing the danger of groundwater contamination. ${ }^{77}$ However, drilling at deeper depths results in higher costs because these coal seams "require higher injection and operating pressure, and increase the cost of any subsequent pump-and-treat option." ${ }^{78}$ In global UCG trials, UCG has been carried out down to 1,200 metres below ground.

Scientists recommend that the target coal seam for UCG should not be located in proximity to a major aquifer with potable water. ${ }^{79}$ Major aquifers should be at least twice the stable cavity height away from project site. ${ }^{80}$ This is because thin layers of overburden can collapse during the gasification process and thus connect an aquifer to the coal seam. ${ }^{81}$ Other important site selection criteria are the coal rank ${ }^{82}$ and other coal properties, such as the dip of coal seams and the water content of the adjoining rocks. ${ }^{83}$

\section{Controlled Burning of CoAl In THE SubSURFACE}

A concern with respect to all coal operations, including UCG, is the risk of uncontrollable coal seam fires. Coal fires may be the result of a natural event (for example, a lightning strike) or industrial activities, such as coal mining. Once coal catches fire the seams can burn for several centuries. ${ }^{84}$ Coal seam fires exist around the world and may present environmental

75 Burton, Friedmann \& Upadhye, ibid at 90. Coal seams at depths of less than 60 m are not considered to be suitable for UCG, for example because of the proximity of potable and potentially potable groundwater sources. Seams, as shallow as $60 \mathrm{~m}$, are usually extracted by surface mining (Shafirovich \& Varma, ibid 7873).

$76 \quad$ Shafirovich \& Varma, ibid at 7873; Burton, Friedmann \& Upadhye, ibid at 93.

77 Shafirovich \& Varma, ibid at 7873; Burton, Friedmann \& Upadhye, ibid at 53.

78 Burton, Friedmann \& Upadhye, ibid at 53. Kempka et al estimate EUR €3,000 per metre of drilling. For more information about the costs of a UCG project, see Kempka et al, supra note 56 at 47.

79 Stephens, Hill \& Borg, supra note 43 at 4; ERCB-AGS, supra note 2 at 26. The US trials at Hoe Creek and Williams resulted in significant groundwater contamination because they took place within potable aquifers and at shallow depth (Burton, Friedmann \& Upadhye, ibid at 93; Moorhouse, Huot \& McCulloch, supra note 58 at 6).

80 Stephens, Hill \& Borg, ibid at 4; Burton, Friedmann \& Upadhye, ibid at 53. For explanations about stable cavities during the gasification process, see e.g. Zaiquan Wang, Li Yu \& Anzeng Hua, "Dynamic Stability Analysis of Cavity and Controlling Associated with UCG” in Guo Yuguang \& Tad S Golosinksi, eds, Mining Science and Technology (Rotterdam: AA Balkema, 1996) 333 at 333-36.

81 Burton, Friedmann \& Upadhye, ibid at 53.

82 Coal Rank refers to a classification that "is based on the fixed carbon, volatile matter, and heating value. It is an indication of the progressive alteration, or coalification, from lignite to anthracite. Rank can also be determined by measuring the reflectance of vitrinite, one of the several organic components (macerals) of coal.” Lignite is the lowest rank of coal, then followed by subbituminous coal (black lignite), bituminous coal (soft coal). Anthracite (hard coal) is the highest rank of economically usable coal) and meta-anthracite is the highest rank of coal but a low-quality fuel (Energy Information Administration (EIA), Coal Data: A Reference (Washington, DC: EIA, 1995) at 115).

$83 \quad$ Shafirovich \& Varma, supra note 30 at 7873.

84 Glenn B Stracher \& Tammy P Taylor, "Coal Fires Burning Out of Control Around the World: Thermodynamic Recipe for Environmental Catastrophe” (2004) 59 International Journal of Coal Geology 7 at 7. 
and social catastrophes. ${ }^{85}$ In the case of UCG, scientists stress that coal is ignited in a controlled manner. In order to burn, coal needs oxygen. Deep coal is not exposed to oxygen and oxygen has to be introduced via the injection well in order to start the burning process. In other words, "when oxygen injection is terminated, gasification ceases and the system progressively cools down. There is therefore no risk of the gasification process 'running out of control'." ${ }^{86}$ However, there are situations where the burning process could be harder to control. UCG requires the use of injection and production wells. Where there are other wells in the area such as water, gas, and oil wells, there is a risk of communication such that UCG gases could contaminate the other wells, ${ }^{87}$ or the other wells could become a "secondary source of oxygen underground reducing the control operators have over the UCG process." ${ }^{88}$

\section{WATER IMPACTS}

Commercial scale projects in the former Soviet Union caused widespread ground water contamination which persisted for a period of up to five years after the end of production. ${ }^{89}$ Environmental data from US trials in Hanna and Hoe Creek showed that UCG at shallow depth posed a significant risk to groundwater in adjacent strata. ${ }^{90}$ Thus, commercial UCG application will require more environmental impact studies, in particular with regard to ground water pollution. As one commentator notes,

[t]he underground gasification cavity is a source of both gaseous and liquid pollutants. They are created as a by-product of the gasification and pyrolysis processes, and may further react with the surrounding strata or dissolve in nearby groundwater. The risk of groundwater pollution from UCG depends on whether the contaminants can migrate beyond the immediate reaction zone to more sensitive groundwater areas. The transport of aqueous phase contaminants depends on the permeability of in-situ rocks, the geological setting of the gasification reactor and the hydrogeology of the area. ${ }^{91}$

The US Environmental Protection Agency (EPA) assumes that most of the injected materials, such as air or oxygen

are not likely to create contaminants at levels exceeding maximum contaminant levels (MCL) or health advisory levels (HAL), but, if they enter a USDW [underground source of drinking water], may unfavorably alter its characteristics, including temperature and gas saturation. The use of ignition or explosive agents, such as propane or ammonium nitrate, to initiate combustion or rubbleize the coal seam may directly create contamination of USDW. USDW contamination also can result from combustion byproducts, residuals such as ash and hydrocarbons, or from mineral-water-gas reactions induced by operations. Ash typically contains many toxic metals such as arsenic, lead, mercury, selenium and chromium. Residual hydrocarbons include tars, polynuclear aromatic and heterocyclic compounds. It is also important to note that use of the UCG site

Environmental effects include the emission of noxious gases and particulates into the atmosphere. Social effects of coal fires include loss of life, relocations of entire communities and abandonment of homes (Stracher \& Taylor, ibid at 8).

Martin Sury et al, Review of Environmental Issues of Underground Coal Gasification (Report No COAL R272 DTI/Pub URN 04/1880, November 2004) at 14.

Moorhouse, Huot \& McCulloch, supra note 58 at 11 refers to the Laurus project in Alberta (see above) where several wells, for different purposes, have been drilled into the Ardley coal seam.

Moorhouse, Huot \& McCulloch, ibid at 11.

Liu Shu-qin et al, supra note 51 at 467.

Ibid at 467.

Ibid. 
for CCS may increase the mobility of many of these contaminants in that organics typically have high solubilities in $\mathrm{CO}_{2}$, and metals are mobilized under acidic aqueous conditions. ${ }^{92}$

UCG projects should not be sited in proximity to potable aquifers. ${ }^{93}$ Further, UCG projects should take place at depths well below fresh water systems. Water at depths of 150 to 200 metres are usually too saline for conventional uses. However, there are fresh water sources much deeper than 500 metres. Another approach is to identify a zone of permanently unsuitable (PU) groundwater. PU groundwater is defined as "a block of strata where the water quality and/or yield are so poor that groundwater in that area cannot realistically be regarded as an environmentally or economically significant 'aquifer.",94 In summary, the literature recommends avoiding UCG projects in proximity to potable sources of water. ${ }^{95}$

\section{SUBSIDENCE}

Another problem is subsidence as a result of the evacuation of coal from depths, akin to long-wall mining: $:^{96}$

Conversion of coal to syngas in-situ and extraction results in inevitable mass transfer to the surface and evacuation of the volume utilized, forming a cavity in the underground reactor. This volume removal leads to stoping of the coal, sidewall collapse and spallation, limited to substantial roof collapse of the cavity, and potentially subsidence above the reactor zone.... The magnitude and form of the subsidence is a function of many factors, including the seam depth (thickness of the overburden), effective rock stiffness and yield strength, fracture density and orientation, structural disposition of the seam, and in-situ stress tensor. ${ }^{97}$

A solution to this problem is proper site selection and leaving walls and pillars in place. Subsidence is more problematic for shallow UCG projects but it has to be managed for all UCG projects. ${ }^{98}$

\section{LAND-USE IMPACTS AND LAND-USE RESTRICTIONS}

The pilot projects in Alberta will only require a small number of wells. However, the Pembina Institute points out that commercial UCG operations will require two to three times more land and several hundred wells spaced 30 to 100 metres apart. ${ }^{99}$ With respect to landuse restrictions, Evgeny Shafirovich and Arvind Varma conclude that "[t]here is no indication in the literature that UCG should be farther from towns, roads, and other objects than underground mines, assuming that the process design and environmental monitoring eliminate water contamination and air pollution. Thus, land-use restrictions developed for underground mining operations can be applied to potential UCG sites."100 
6. UNDERGROUND COAL GASIFICATION:

POLLUTION REDUCTION AND CARBON MANAGEMENT

This section analyzes the potential of UCG to reduce pollutants and harmful air emissions compared to conventional coal technology. The first part focuses on its potential to reduce emissions and pollutants compared to conventional coal mining and combustion. The second part specifically deals with UCG combined with carbon capture and storage and its potential to reduce $\mathrm{CO}_{2}$ emissions.

a. Underground Coal Gasification, Air Emissions, and Reduction of Pollutants

Produced syngas contains air contaminants, such as nitrogen oxides, sulphur dioxide, particulate matter, and volatile trace elements, such as mercury, arsenic, and selenium. ${ }^{101}$ Greenhouse gases in the syngas are $\mathrm{CO}_{2}$ and $\mathrm{CH}_{4} \cdot{ }^{102}$ Before the syngas is used for combustion, it must be cleaned. ${ }^{103}$ Moorhouse et al. conclude that the principal advantages of UCG with respect to the reduction of pollutants are that, inter alia: "[m]ost of the ash in the coal stays underground, thereby avoiding the need for excessive gas clean-up, and the environmental issues associated with fly ash waste stored at the surface."104 This means produced volatile trace elements (mercury, arsenic, and selenium) and sulphur remain in the underground cavity. ${ }^{105}$ Also, pollutants like sodium oxide $\left(\mathrm{SO}_{\mathrm{x}}\right)$ and nitrogen oxide $\left(\mathrm{NO}_{\mathrm{x}}\right)$ are reduced in volume. ${ }^{106}$ In conventional coal combustion, these pollutants have to be separated from the flue gas at higher costs. ${ }^{107}$

The next section deals with UCG and its potential for economically sequestering $\mathrm{CO}_{2}$ in the combustion cavity or adjacent strata. ${ }^{108}$

\section{b. Carbon Capture and Storage}

The syngas from UCG operations contains $\mathrm{CO}_{2}$. Kempka and others note that "[t]he quantity of $\mathrm{CO}_{2}$ that can be captured from the synthesis gas produced as a result of the UCG operation will vary according to the chemical composition of the product gas." ${ }^{109}$ Carbon dioxide can be used for industrial processes and applications, such as enhanced oil recovery

Moorhouse, Huot \& McCulloch, supra note 58 at 10.

For example, the $\mathrm{CH}_{4}$ in the syngas will result in water and $\mathrm{CO}_{2}$ during combustion. Thus, the flue gas from the power plant has to be cleaned too, in order to reduce air pollution. For an overview about the technologies for the removal of $\mathrm{CO}_{2}$, see Martin M Halmann \& Meyer Steinberg, Greenhouse Gas Carbon Dioxide Mitigation — Science and Technology (Boca Raton: Lewis Publishers, 1999) at 137-39. Burton, Friedmann \& Upadhye, supra note 16 at 54. For example, for Laurus prospective commercial facility, Laurus will clean the syngas near the UCG site and then transport it to the power generation facility where it is combusted (Moorhouse, Huot \& McCulloch, supra note 58 at 10). There is a variety of technologies to clean the syngas. Particulates and tars can be removed by cyclones, bag-house filters and electrostatic precipitators. Sulfur compounds can be removed with acid gas removal technologies (Burton, Friedmann \& Upadhye, ibid at 54). Moorhouse, Huot \& McCulloch, ibid at 11.

Moorhouse, Huot \& McCulloch, ibid; Burton, Friedmann \& Upadhye, ibid at 14.

Burton, Friedmann \& Upadhye, ibid at 14.

Moorhouse, Huot \& McCulloch, supra note 58 at 11.

Burton, Friedmann \& Upadhye, supra note 16 at 14-15.

Kempka et al, supra note 56 at 48. See also Part 2 for an explanation of the UCG process. 
(EOR) ${ }^{110}$ refrigeration, fire fighting, fire extinguishers, and carbonated beverages. ${ }^{111}$ Carbon dioxide quantities that exceed any industrial use could be disposed of in suitable geological formations. ${ }^{112}$ There are several technologies available to remove the $\mathrm{CO}_{2}$ from the syngas, for example, sorbent systems, membrane separation, and cryogenic separation. ${ }^{113}$

UCG combined with CCS is considered to be an attractive carbon management strategy because of the carbon capture economics and the coincidence of storage targets. ${ }^{114}$ CCS makes use of deep saline aquifers, active oil fields for EOR, depleted oil or gas fields, and unmineable coal seams. Scientists note that storage opportunities are often found in coal basins. Therefore they presume a coexistence of storage sites and UCG sites. ${ }^{115}$ According to Friedmann et al, there is a high degree of coincidence between coal resources and potential sequestration sites in North America, India, and China. Estimates indicate that 75 percent of UCG pilot projects are situated within 50 kilometres of prospective saline aquifers, depleted oil and gas fields, and EOR possibilities. ${ }^{116}$ This offers operators the option to co-locate UCG and CCS projects in an area that is likely suitable for effective $\mathrm{CO}_{2}$ storage. ${ }^{117}$ UCG cavities deeper than 800 metres may be used for CCS. ${ }^{118}$

Julio Friedmann, Ravi Upadhye, and Fung-Ming Kong note that "[f]or a UCG-CCS operation aimed at conventional sequestration targets, there may be synergies in site characterization and monitoring where work done for the CCS project component could be coordinated with UCG component or vice versa. It may also be possible to pair pipeline networks $\left(\mathrm{CO}_{2}\right.$, syngas, $\left.\mathrm{SNG}\right)$ in terms of permitting and rights-of-way, again reducing incremental costs." ${ }^{119}$ From an economic view, CCS projects utilizing gasified coal seams tends to be feasible because the drilling infrastructure used for UCG may also be used for $\mathrm{CO}_{2}$ injection, ${ }^{120}$ which saves additional drilling costs. Finally, some scholars argue that UCG coupled with CCS will help to increase public acceptance for UCG. ${ }^{121}$ Considering the low level of public acceptance of CCS in countries such as Germany, this assumption is open to question. $^{122}$

UCG, combined with surface combustion, produces less greenhouse gases than conventional mining. UCG with power generation may reduce greenhouse gases by 25 percent compared to a supercritical coal plant on a megawatt hour (MWh) basis, even

See e.g. Swan Hills project, online: <http://swanhills-synfuels.com/>.

ERCB-AGS, supra note 2 at 33.

ERCB-AGS, ibid at 33.

Halmann \& Steinberg, supra note 102 at 135-48; Burton, Friedmann \& Upadhye, supra note 16 at 5455, 83.

114 For detailed information about the UCG-CCS economics see Kempka et al, supra note 56; Burton, Friedmann \& Upadhye, ibid at 82.

Burton, Friedmann \& Upadhye, ibid at 82.

Friedmann, Upadhye \& Kong, supra note 15 at 4554.

Ibid at 4554-55.

Shafirovich \& Varma, supra note 30 at 7873.

Friedmann, Upadhye \& Kong, supra note 15 at 4555.

Kempka et al, supra note 56 at 45.

Friedmann, Upadhye \& Kong, supra note 15 at 4556.

See for example Federal Ministry of Economics and Technology, "Public Engagement and CCS Regulation - The German Experience” (2011), online at: <http://www.iea.org/media/workshops/2011/ ccstalk/Fischer.pdf>; Jonas Helseth, “CCS in Germany — Is it Game over?” online: Global CCS Institute <http://www.globalccsinstitute.com/cmmunity/blogs/authors/jonashelseth/2011/10/10/ccsgermany-it-game-over>.
} 
without post-combustion carbon capture and storage. ${ }^{123}$ The Pembina Institute estimates capture costs of a UCG $\mathrm{CO}_{2}$ stream ranging from $\$ 50$ to $\$ 100$ per tonne of $\mathrm{CO}_{2}$. The real advantage of UCG over surface gasifiers is that UCG does not require a gasifier because the coal is gasified in the coal seam. Therefore, the Pembina Institute estimates that the relatively low capture costs, without costs for a gasifier, will result in low carbon capture costs compared to other power generation facilities. ${ }^{124}$

\title{
7. SUMMARY
}

The advantages of UCG are especially visible when we compare UCG with conventional coal mining and surface gasification. UCG leaves ash and organic residues underground whereas in the case of surface gasification, the leachate from these substances could accumulate on the surface and contaminate surface or ground water. ${ }^{125}$ In sum, the environmental advantages of UCG are "no discharge of tailings, reduced sulfur emissions and reduced discharge of ash, mercury and tar." ${ }^{\text {"26 }}$ UCG syngas is similar to syngas from a surface gasifier, but UCG syngas has much lower tar and ash content compared with gas from a surface gasifier. ${ }^{127}$ Mining safety is another important aspect. UCG technology does not require people underground and thus avoids the safety and health risks associated with underground mining. ${ }^{128}$ However, UCG technology cannot be controlled to the same extent as surface coal gasification:

\begin{abstract}
Many important process variables, such as the rate of water influx, the distribution of reactants in the gasification zone, and the growth rate of the cavity, can only be estimated from measurements of temperatures and product gas quality and quantity. The primary engineering control is the rate and composition of the injected oxidant (air or $\mathrm{O}_{2}$ ), however the appropriate response to manage pressure and injection composition is not well understood. ${ }^{129}$
\end{abstract}

\section{CONCLUSION}

This section highlighted some of the challenges associated with UCG technology. These challenges in UCG technology have to be overcome before UCG can be applied commercially. ${ }^{130}$ Because UCG is in a development stage, it might be difficult to appropriately regulate UCG and thus, regulators will need to be able to adapt the regulatory framework as knowledge and experience is obtained.

Scientists stress that the correct assessment of site geology is a key component of avoiding environmental risks and contamination. Elizabeth Burton, Julio Friedmann, and Ravi

Moorhouse, Huot \& McCulloch, supra note 58 at 8; Schulten, supra note 17 at 39; Burton, Friedmann \& Upadhye, supra note 16 at 39-41.

Moorhouse, Huot \& McCulloch, ibid at 8. For detailed information and comparison about the $\mathrm{CO}_{2}$ capture costs of various power generation facilities, see Bert Metz et al, eds, IPCC Special Report on Carbon Dioxide Capture and Storage (New York: Cambridge University Press, 2005) at 259-64. Burton, Friedmann \& Upadhye, supra note 16 at 58.

Liu Shu-qin et al, supra note 51 at 467.

See explanations at II.C.6.a and II.C. In addition, Friedmann, Upadhye \& Kong, supra note 15 at 4553; Burton, Friedmann \& Upadhye, supra note 16 at 56.

Burton, Friedmann \& Upadhye, ibid at 59.

Friedmann, Upadhye \& Kong, supra note 15 at 4555.

There are R\&D gaps that are not part of this article. For information about R\&D gaps see Burton, Friedmann \& Upadhye, supra note 16 at 97-106. 
Upadhye recommend that the sites should be located "at depths where local aquifers consist of saline, nonpotable water, with statigraphic seals, with structural integrity, including no possibility of cavity roof caving that would create connectivity with other adjacent potable aquifers." ${ }^{131}$ The same authors conclude that "with optimization of UCG operations and careful site selection, it is likely that UCG can meet an acceptable level of environmental risk, equivalent to or less than the risks posed by conventional mining and surface gasification."132

Now the article turns to the legal and regulatory aspects with regard to UCG. The next section deals with property rights with respect to land and coal and related access rights to the surface under the laws of Alberta.

\section{CoAl ANd Property Rights in Alberta}

\section{A. Property Rights in LAND AND Minerals}

Canadian law permits the severance of the ownership of the surface land and ownership of the minerals. ${ }^{133}$ One person may own the surface while another person owns all or some of the minerals. ${ }^{134}$ Where ownership of the land and minerals has been severed, it must be determined who owns which minerals and what rights the mineral owner has to enter and access the surface in order to reach the minerals. ${ }^{135}$ Two types of ownership have to be distinguished. The Crown can be the owner of the land or minerals or the land or minerals may be owned by private parties (so called freehold land ${ }^{136}$ or freehold minerals). A further distinction has to be made in those cases where the mineral rights, for example, to coal and natural gas are not held by the same person. This is called a "split title."137 In Alberta, 81 percent of the subsurface mineral rights are owned by the Crown. The remaining 19 percent are owned by the Government of Canada in national parks or held on behalf of First Nations, individuals, or corporations as a result of land grants made by Canada in the 1800s (freehold mineral rights). ${ }^{138}$ The Crown owns most of the coal in Alberta. ${ }^{139}$ During an average year, around 50 to 60 percent of the extracted Albertan coal comes from Crown leases, and the remaining part comes from privately owned leases. ${ }^{140}$

Other recommendations are, inter alia, balancing operating conditions to minimize outward transport of contamination from greatly over-pressurized burn-zones, and if possible, removing liquid accumulations of undissolved pyrolysis products (Burton, Friedmann \& Upadhye, ibid at 57, 60-61).

Burton, Friedmann \& Upadhye, ibid at 59.

Bruce Ziff, Principles of Property Law, 5th ed (Scarborough: Carswell, 2010) at 94.

Barry J Barton, Canadian Law of Mining (Calgary: Canadian Institute of Resources Law, 1993) at 28.

Barton, ibid at 28, 34. Barton describes surface rights as a "shorthand expression to mean the balance of the rights in the land once the mineral rights are separated."

Simply stated, "freehold lands" are lands which are privately held, that is, by an individual or a company, as opposed to lands held by the Crown in right of Canada or a province. "Freehold ownership" is ownership of an estate in fee simple, such fee simple ownership being the highest form of an estate in land. The bundle of rights associated with fee simple ownership includes mineral ownership, which continues forever (Janice Buckingham \& Patricia Steele, "Coalbed Methane: 'Conventional Rules for an Unconventional Resource'” (2004) 42:1 Alta L Rev 1 at 3). Anderson v Amoco Canada Oil \& Gas, 2004 SCC 49, [2004] 3 SCR 3; Buckingham \& Steele, ibid at 4.

Alberta Energy, Mineral Rights, Freehold Mineral Rights and a historical overview of Mineral Rights ownerships, online: Government of Alberta <http://www.energy.alberta.ca/Tenure/pdfs/FMT_historical overview.pdf $>$.

Ibid. 
General property law applies to freehold minerals. Specialized legislation applies to Crown-owned minerals, for example, the $M M A^{141}$ and the Public Lands Act. ${ }^{142}$ Parts of the MMA, the Coal Conservation Act, ${ }^{143}$ and the Oil and Gas Conservation Act ${ }^{144}$ apply to Crown-owned and privately owned minerals.

Alberta Energy is responsible for the administration of the $M M A \cdot{ }^{145}$ Pursuant to section 2, the $M M A$ applies to the following: (a) to all mines and minerals, ${ }^{146}$ pore space and related natural resources vested in or belonging to the Crown in right of Alberta; and (b) where the context so permits or requires, to all wells, mines, quarries and minerals in Alberta. No disposition may be made of an estate in a mineral owned by the Crown in right of Alberta unless the disposition is specifically authorized by the $M M A$ or another Act. ${ }^{147}$ For example, sections 64 to 72 of the MMA for coal and sections 80 to 86 of the MMA authorize the disposition of mineral rights for petroleum and natural gas.

Section 30(1) of the CCA requires that an applicant for a scheme approval for an in situ coal project must be entitled to the rights to both the coal and the petroleum and natural gas in the target coal seam (whether from the Crown or private owner). ${ }^{148}$ This requirement eliminates a potential conflict between the holders of rights to different resources since it requires a UCG operator to hold titles to coal and the petroleum and natural gas in the coal seam. ${ }^{149}$ The potential UCG operator has to obtain all these mineral rights because the right to coal alone does not grant rights to petroleum and natural gas, including coalbed methane. ${ }^{150}$

\section{B. ACCESS TO THE SURFACE: The SURFACE RIGHTS ACT}

In Alberta, the owner of the land or surface might not own the mineral rights. ${ }^{151}$ In that situation, the mineral owner cannot grant the right of entry to the surface of the respective land where the UCG project is going to take place. In such a case, the lessee or project operator needs to obtain the consent of the owner or occupant of the surface for access or a right of entry order from the Surface Rights Board (SRB). ${ }^{152}$ For public or Crown land,

The MMA, supra note 55, principally deals with Crown-owned minerals but sections 2 and 3 contemplate that some sections (such as s 10.1) will apply to all lands in Alberta, see Encana Corporation v Devon Canada Corporation, 2012 ABCA 271, 536 AR 199.

RSA 2000, с P-40.

RSA 2000, c C-17 [CCA].

RSA 2000, c O-6 [OGCA].

See Government Organization Act, RSA 2000, c G-10; Designation and Transfer of Responsibility Regulation, Alta Reg 80/2012, s 6 [Responsibility Regulation].

Pursuant to section 1(1) of the MMA, supra note 55, minerals are defined as "all naturally occurring minerals, and without restricting the generality of the foregoing, includes (i) ... coal.” MMA, ibid, s 11(1).

CCA, supra note 143 , s 30(1).

Coalbed methane involved uncertainty regarding who holds the title to the gas, the coal rights owner or the natural gas owner. This issue is resolved since Encana Corporation v Devon Canada Corporation, supra note 141 . Now also in the MMA, supra note 55, s 10.1.

MMA, supra note 55, ss 10.1, 67(1).

Cabre Exploration Ltd v Arndt, (1988), 55 DLR (4th) 480 (ABCA); Thomas R Owen, "Surface Rights Overview: The Four Realities" in Access to Surface Rights for Oil and Gas Operations (Ontario: Insight Press, 1996) at 17; Ziff, supra note 133.

Surface Rights Act, RSA 2000, c S-24, ss 12(1), 15 [SRA]. Section 12(1) of SRA:

No operator has a right of entry in respect of the surface of any land

(a) for the removal of minerals contained in or underlying the surface of that land or for or incidental to any mining or drilling operations,

(b) for the construction of tanks, stations and structures for or in connection with a mining or 
Alberta Environment and Sustainable Resource Development (AESRD) will issue approvals. ${ }^{153}$ However, approvals can only be issued if they are in compliance with designated land use according to the Alberta Land Stewardship Act. ${ }^{154}$ ALSA, among other things, provides a means to manage activities required to meet the reasonably foreseeable needs of Albertans. ${ }^{155}$ It serves as an umbrella framework that provides the Lieutenant Governor in Council with the power to divide Alberta into different planning regions and to set up regional plans. ${ }^{156}$ Pursuant to section 20 of the REDA, the AER must carry out its powers in accordance with any applicable $A L S A$ regional plan and approvals also must comply with applicable ALSA regional plans.

A Surface Rights Board right of entry order grants "the right of entry, user and taking of the surface of land." Sections 12 to 14 of the SRA stipulate the activities covered by a right of entry order include not only the actually mining operations but also any necessary access road. ${ }^{157}$ In return for the right of entry, the lessee or operator must pay compensation in an amount ordered by the SRB. ${ }^{158}$ Thus, a UCG project operator that holds the mineral rights must also obtain either the consent of the surface owner and the occupant of the land or a right of entry order.

The following part comments on the regulatory framework for UCG operations in Alberta. It discusses both the pre-2011 scheme, which was in force when two UCG projects were approved, as well as the current regulatory framework, including changes made due to Bill 16. ${ }^{159}$ The next part also elaborates on liability aspects with respect to UCG activities in Alberta.

\section{UNDERGROUND COAL GASIFICATION: THE REgUlATORY FrAMEWORK IN ALBERTA}

\section{A. LEGISLATIVE DEVELOPMENT FOR UNDERGROUND COAL GASIFICATION IN ALBERTA}

Prior to 2011, Alberta did not have a specific set of rules to deal with UCG. Instead, UCG projects were reviewed and approved under the provisions of section 39 of the OGCA, ${ }^{160}$ which deals with experimental gas recovery schemes. ${ }^{161}$ The UCG applications led the ERCB

drilling operation, or the production of minerals, or for or incidental to the operation of those tanks, stations and structures,

(c) for or incidental to the construction, operation or removal of a pipeline,

(d) for or incidental to the construction, operation or removal of a power transmission line, or

(e) for or incidental to the construction, operation or removal of a telephone line

until the operator has obtained the consent of the owner and the occupant of the surface of the land or has become entitled to right of entry by reason of an order of the Board pursuant to this Act. Responsibility Regulation, supra note 145, s 8; Public Lands Act, supra note 142.

RSA 2009, c A-26.8 [ALSA]. See Jenette Poschwatta-Yearsley \& Adam Zelmer, "The Alberta Land Stewardship Act: Certainty or Uncertainty?” (2009) 106 Resources 1.

ALSA, ibid, s 1(2)(b).

Ibid at ss 3-4.

SRA, supra note 152, s 12(3)(b)(i)(ii).

$S R A$, ibid at ss 1(m), 1(b), 23 (compensation order). See also Part IV.F.1 below for the types of damage covered under the SRA.

Bill 16, Energy Statutes Amendment Act, 4th Sess, 27th Parl, Alberta 2011.

OGCA, supra note 144.

The ERCB approved the first UCG project as an experimental gas scheme under the OGCA in 2008. ERCB 2009, supra note 25 at 1; Moorhouse, Huot \& McCulloch, supra note 58 at 13. 
to review the $C C A^{162}$ and the OGCA. The review revealed the need for a regulatory framework that clearly and explicitly addressed UCG projects and to that end the ERCB formed a multidisciplinary team to propose a regulatory framework for UCG projects. The team reviewed UCG legislation from the US, Australia, South Africa, Russia, and Europe but came to the conclusion that these regimes were not appropriate in the context of the existing Alberta regulatory regime. ${ }^{163}$ The result was Bill 16 in 2011, which proposed a series of UCG-specific amendments to various provincial statutes. ${ }^{164}$

In order to provide context for the current regulatory UCG framework, the next section briefly reviews the approval process that was used for the first two UCG projects in Alberta, the Swan Hills and Laurus projects.

\section{B. THE “OLD” REGIME: REGULATORY APPROVALS FOR THE SWAN HILLS AND LAURUS PROJECTS ${ }^{165}$}

Swan Hills and Laurus were approved under section 39 of the OGCA for experimental gas recovery schemes. In addition, these two UCG projects required other different approvals as well, for example under the Environmental Protection and Enhancement Act ${ }^{166}$ or the Water Act, ${ }^{167}$ due to their technical differences and locations.

On the environmental side of the Swan Hills approval, Alberta Environment, administering the EPEA, concluded that the project "is a pilot project with low emissions and minor disturbance" that does not require a formal approval under the EPEA. ${ }^{168}$ Compared with Laurus' applications, the Swan Hills project did not require as many approvals. Swan Hills uses only non-fresh injection water from nearby oilfields that is only used as the primary source during start up and will continue to be used as makeup water. ${ }^{169}$ The water will be trucked to site, and the produced water will be recycled and reused for the gasification process so that no water will be discharged at the surface. ${ }^{170}$

Laurus $^{171}$ filed for approval with Alberta Environment to construct and operate the demonstration project and to develop, operate, and reclaim components of the demonstration project under the EPEA. The Laurus project also filed for approval to dewater groundwater, construct an access road through a wetland, and to disturb a water body (the Ardley Coal Seam) under the WA. In addition, Laurus filed applications for: clearance to construct the

CCA, supra note 143.

These countries "were not found to be useful precedents as the legislation was limited in scope and the regulatory process were significantly different from that of Alberta. Instead, existing ERCB legislation was reviewed to determine how it could be amended to include in situ coal development”( ERCB 2009, supra note 25 at 1 ).

Energy Statutes Amendment Act, supra note 159.

This section is based on the project applications and approvals which are on file with the ERCB.

RSA 2000, c E-12 [EPEA].

RSA 2000, c W-3 [WA].

Swan Hills project application, supra note 53 at Appendix A - AENV letter dated 26 June 2007. However, Alberta Environment pointed out that the project has to be carried out in compliance with all relevant provisions of the EPEA and other provincial requirements.

Swan Hills project application, ibid at 4, 8 .

Ibid at 8.

The application numbered 1625048 concerning the construction and operation of an experimental gas recovery scheme was approved on 16 March 2011 (approval no 11589). 
facilities under the Historical Resources Act; ${ }^{172}$ well licenses under the OGCA; clearance for construction and operation of pipelines under the Pipeline Act; ${ }^{173}$ and a development permit from Parkland County under the Municipal Government Act. ${ }^{174}$

\section{THE CURRENT REgULATORY FRAMEWORK FOR UNDERGROUND COAL GASIFICATION IN ALBERTA}

The REDA made recent changes in the energy regulatory framework. However, the $R E D A^{175}$ does not carry fundamental changes in substance for UCG activities. Rather, the changes rather impact the new energy regulator and its competencies in energy matters. ${ }^{176}$ REDA dissolves the $\mathrm{ERCB}^{177}$ and establishes a new regulator: the AER, which is responsible, among other things, for coal related projects. ${ }^{178}$

The new regulatory framework, as of 13 May 2011 is based on the Coal Conservation Regulations, ${ }^{179}$ the OGCA and the Oil and Gas Conservation Rules. ${ }^{180}$ The aspects of a UCG project that are related to the coal itself are regulated under the CCA. Other activities that are similar or identical to oil and gas development, such as the drilling of wells, are now included under the OGCA. The approval for in situ coal schemes is now set out in section 29 of the CCA rather than section 39 of the OGCA. Wells and other facilities will be licensed under the OGCA. The construction of a pipeline at the UCG site will be regulated and approved under the Pipeline Act. ${ }^{181}$

The amended CCA contains redefined and new terms such as coal, coal seams, evaluation well, observation well, in situ coal gasification, in situ coal liquefaction, in situ coal scheme, synthetic coal gas, and synthetic coal liquid. Section 1(1)(f.2) of the CCA defines "in situ" coal gasification as the "thermal or chemical conversion of coal into synthetic coal liquid in an underground coal seam using an industrial process." ${ }^{\text {"182 }}$ In situ coal liquefaction means the thermal or chemical conversion of coal into synthetic coal liquid in an underground coal seam using an industrial process according to section 1(1)(f.3). The more generic term in situ coal scheme refers to an operation for the purpose of in situ coal gasification or in situ coal liquefaction, according to section 1(1)(f.4).

RSA 2000, с H-9.

RSA 2000, с P-15.

RSA 2000, c M-26. Laurus project application, supra note 66 at 2-2.

REDA, supra note 22.

For more information on REDA, see e.g. Nickie Vlavianos, “An Overview of Bill 2: Responsible Energy Development Act - What are the changes and What are the issues?” (15 November 2012), online: Ablawg <http://www.ablawg.ca/2012/11/15/an-overview-of-bill-2-responsible-energy-development-actwhat-are-the-changes-and-what-are-the-issues/>.

REDA, supra note 22, s 81.

REDA, ibid at ss 1(1)(i), (j)(i), 2(2)(a), 3. The AER is now responsible for Alberta's energy resource statutes and regulations, which includes the CCA, OGCA, and Pipeline Act but also the responsibilities of the ESRD under the EPEA, Public Lands Act and WA (Vlavanios, supra note 176 at 2). Section 86 of the REDA did not make substantial changes for the CCA. The more important changes of the CCA occurred during the implementation of Bill 16.

Alta Reg 270/1981 [CCR].

Alta Reg 151/1971 [OGCR]. The ERCB used the regulatory model of the OGCA, OGCR, Pipeline Act, and Pipeline Regulation (Alta Reg 91/2005) as an analog for similar components in the UCG process, such as wells, pipelines, and facilities. From a regulatory view, UCG have similar stages compared with in situ oil sands development. UCG and in situ oil sands development both require the drilling of wells for resource recovery.

Supra note 173.

Supra note 143. 


\section{APPlication REQUIREMENTS}

\section{COAL CONSERVATION ACT}

The CCA applies to in situ coal schemes in Alberta and authorizes the AER to make rules relating to specified aspects of in situ coal schemes. ${ }^{183}$ Part 6 of the CCA regulates the development, operation, and abandonment of in situ coal schemes, including experimental in situ coal schemes. ${ }^{184}$ "Experimental" refers to methods that are untried or unproven. ${ }^{185}$ Persons who want to undertake any operations preparatory or incidental to the drilling, construction, or operation of an in situ coal scheme other than drilling an evaluation well, must obtain an approval from the AER ${ }^{186}$ For site evaluation purposes a proponent needs only a licence for the evaluation well and not a scheme approval.

Further, before beginning to drill a well or construct a pipeline or facility associated with an in situ coal scheme, or before undertaking any operations preparatory or incidental to the drilling of a well or the construction of a pipeline or facility associated with an in situ coal scheme, the project applicant must hold an approval for the in situ coal scheme, and a license for the well or facility under the OGCA (sections 11 and 12). With respect to a pipeline, the person must hold a license under the Pipeline Act. ${ }^{187}$

Briefly summarized, the CCA requires that evaluation, injection, and production wells are licensed under the OGCA.

Part 6 of the CCA also provides specific requirements for in situ coal schemes with respect to suspension and abandonment, ${ }^{188}$ and cancellation or suspension of approval or license. ${ }^{189}$ The AER may make rules that require the holder of the approval to provide deposits, a letter of credit, or other forms of security to guarantee the proper and safe suspension and abandonment of in situ coal schemes. ${ }^{190}$ The AER has yet to make use of this power, but the AER did revise Directive 020, dealing with Well Abandonment (1 July 2010). Directive 020 provides that non-routine abandonment operations include abandonment of any well that is associated with an in situ coal gasification scheme. ${ }^{191}$ Non-routine abandonment operations require AER approval before the licensee can commence abandonment. ${ }^{192}$

Ibid, ss 3, 9 .

Ibid, s 28.

Ibid, s 1(1)(e.3).

Ibid, s 29.

Ibid, s 31.1(1); Pipeline Act, supra note 173.

CCA, ibid, s 31.4.

Ibid, s 31.6.

Ibid, ss 31.4(5)-(8), 9(1)(c.1).

Energy Resources Conservation Board (ERCB), Directive 020: Well Abandonment Guide, at section 1.4 at 5.

Directive 020, ibid at s 1.4 . 


\section{OTHER APPLICATION REQUIREMENTS}

The applicant of a UCG project must comply with all relevant ERCB Directives. ${ }^{193}$ To describe the implications of each of these Directives for UCG projects would go beyond the scope of this article, but the issues should be emphasized. Referred to in the ERCB's Proposed Legislative Framework for In Situ Coal Development, ${ }^{194}$ UCG projects must comply with Directive 056 (Energy Development Applications and Schedules), which requires disclosure of detailed technical information with respect to the wells, pipeline, and facility design details. ${ }^{195}$ Furthermore, the applicant for a UCG project has to assess the impact of the in situ coal development on the recovery of other hydrocarbon resources, such as CBM and demonstrate that other resources will not be sterilized or wasted by the in situ development. This requirement will be stipulated in proposed revisions to Directive 061, ${ }^{196}$ which deals with the approval of coal projects. ${ }^{197}$

The revisions to Directive 061 will also stipulate the participant involvement ${ }^{198}$ requirements for in situ coal schemes. The applicant will have to fulfill the minimum requirement under the current Directive 056 and must notify offset mineral rights lessees and lessors within 1.6 kilometres of the boundary of the proposed in situ coal scheme. ${ }^{199}$

Relevant ERCB Directives are for example: Directive 007: Volumetric and Infrastructure Requirements; Directive 008: Surface Casing Depth Minimum Requirements; Directive 009: Casing Cementing Minimum Requirements; Directive 010: Minimum Casing Design Requirements; Directive 017: Measurement Requirements for Upstream Oil and Gas Operations; Directive 019: ERCB Compliance Assurance - Enforcement; Directive 020: Well Abandonment Guide; Directive 036: Drilling Blowout Prevention Requirements and Procedures; Directive 038: Noise Control; Directive 051: Injection and Disposal Wells - Well Classifications, Completions, Logging, and Testing Requirements; Directive 055: Storage Requirements for Upstream Petroleum Industry; Directive 056: Energy Development Applications and Schedules; Directive 057: Fencing and Site Access Requirements for Oil and Gas Facilities; Directive 058: Oilfield Waste Management Requirements for the Upstream Petroleum Industry; Directive 059: Well Drilling and Completion Data Filing Requirements; Directive 060: Upstream Petroleum Industry Flaring, Incinerating, and Venting; Directive 061: How to Apply for Government Approval of Coal Projects in Alberta; Directive 067: Applying for Approval to Hold EUB Licenses; Directive 068: ERCB Security Deposits; Directive 071: Emergency Preparedness and Response Requirements for the Petroleum Industry; Directive 072: Well Abandonment Notification Requirements; Interim Directive (ID) 2001-03: Sulphur Recovery Guidelines for the Province of Alberta. ERCB 2009, supra note 25.

Ibid at 2 .

ERCB, Directive 061: How to Apply for Government Approval of Coal Projects in Alberta (1983), online: <http://www.ercb.ca/docs/documents/directives/directive061.pdf>.

This is indicated in ERCB 2009, supra note 25 at 3 and confirmed by an email dated 23 January 2012 from the ERCB (on file with the author).

Directive 056, supra note 193 at 2-1, states that:

"Participant involvement" is an umbrella term encompassing all aspects of public, industry, and regulator interactions and communications. While the three main participant groups in energy development are industry, the public, and the ERCB, it is recognized that other groups also have a stake in energy development.... Industry is required to develop an effective participant involvement program that includes parties whose rights may be directly and adversely affected by the nature and extent of a proposed application. The development and implementation of this program must occur prior to the filing of an application to Facilities Applications and include distributing the applicant's information package and the required ERCB publications.

See also Shaun Fluker, "Public Participation at the Alberta Energy Resources Conservation Board" (2011) 111 Resources, Canadian Institute of Resources Law 1, online: <http://dspace.ucalgary.ca/ bitstream/1880/48514/1/Resources111.pdf > at 3; Nickie Vlavianos, "The Issues and Challenges with Public Participation in Energy and Natural Resources Development in Alberta” (2010) 108 Resources, Canadian Institute of Resources Law 1, online: <http://dspace.ucalgary.ca/bitstream/1880/47996/1/ Resources108.pdf> at 6-9. 


\section{APPLICATION REQUiREMENTS ACCORDING TO THE ENVIRONMENTAL PROTECTION AND ENHANCEMENT ACT AND THE WATER ACT}

The main environmental statutes and regulations that will apply to UCG projects are: the EPEA ${ }^{200}$ the Environmental Assessment (Mandatory and Exempted Activities) Regulation; ${ }^{201}$ and the $W A .^{202}$ Alberta Environment Sustainable Resource Development (AESRD) administers the EPEA and $W A .{ }^{203}$ However, the REDA transfers responsibility from AESRD to the AER to the extent that the REDA applies to energy resource activities. ${ }^{204}$

The EPEA and the Environmental Assessment Regulation ${ }^{205}$ distinguish between mandatory, exempted, and discretionary activities. Mandatory activities require an environmental assessment while exempted activities do not. UCG project activities do not qualify as mandatory activities. While drilling, construction, operation, or reclamation of an oil or gas well are all exempt activities, there is no specific exemption for UCG projects. ${ }^{206}$ In all other cases, section 44(1)(b) of the EPEA provides that an environmental assessment is discretionary. The "Proposed Legislative Framework for In Situ Coal Development” states that "[i]f AENV [Alberta Environment] deemed it appropriate, it could request an environmental impact assessment and an EPEA approval for an UCG development as a result of the ADR amendment." ${ }^{207}$ Section 60 and 61 EPEA in conjunction with the Activities Designation Regulation ${ }^{208}$ require that an operator needs approval before commencing any activity with respect to an in situ coal scheme. ${ }^{209}$

Depending on the circumstances of the UCG project, operators will likely have to apply for authorizations under the WA for water use and withdrawal. ${ }^{210}$ The AER recommends obtaining a WA approval prior to submitting an in situ coal scheme application but is aware that this might not always be possible. ${ }^{211}$ However, the AER points out that the WA and the AER in situ coals scheme applications will have to be submitted concurrently, ${ }^{212}$ which probably means that both applications have to be submitted together but will be assessed separately.

The next section elaborates on liability issues associated with UCG activities under Alberta law.

Supra note 166.

Alta Reg 111/1993 [Environmental Assessment Regulation].

Supra note 167.

Responsibility Regulation, supra note 145, s 8. For the relationship between the REDA and the WA see Arlene Kwasniak, "The Responsible Energy Development Act and the Water Act - Cloudy Confluences" (7 January 2013), online: Ablawg <http://www.ablawg.ca/2013/01/07/the-responsibleenergy-development-act-and-the-water-act-cloudy-confluences/>.

Supra note 22, ss 88(2), 1(1)(i).

Environmental Assessment Regulation, supra note 201.

Ibid at s 2, Schedule 2(e).

ERCB 2009, supra note 25 at 6.

Alta Reg 276/2003 [ADR].

"Activity" is defined in section 1(a) of the EPEA in conjunction with the Schedule of Activities. An UCG project would qualify as an activity under various aspects of the Schedule, for example: 1, 2(k), (u), 3, 5(a). The $A D R$ defines syngas and syngas plant in section 2(2)(nnn.1)(nnn.2). Pursuant to section 5(1), Schedule 1, Division 2, Part 8 (h)(viii) of the $A D R$, the construction, operation or reclamation of a syngas plant requires an approval (ADR, ibid; EPEA, supra note 166).

ERCB 2009, supra note 25 at 6.

Ibid at 6 .

Ibid at 6 . 


\section{E. LIABILITY FOR UNDERGROUND COAL GASIFICATION ACTIVITIES UNDER Alberta LAW}

UCG activities may result in harm, inter alia, to the environment, for example groundwater contamination and subsidence. They may also affect the property rights of surface land owners. It is also possible that UCG activities could contaminate wells, including water and oil and gas wells. Thus, as with any industrial activity, the operator may be subject to liability claims. Liability and claims for compensation can arise under statute, contract, and tort. This section focuses only on statutory and tort liability.

\section{STATUTORY LiABILITY UNDER THE OIL AND GAS CONSERVATION ACT, THE COAL CONSERVATION ACT, AND THE SURFACE RIGHTS ACT}

The $O G C A^{213}$ stipulates remedial liability in various sections. For example, pursuant to sections 29 and 17(3), the licensees and working interest owners are liable for the proper abandonment, reclamation, and suspension of a well or facility. ${ }^{214}$ If the licensee or working interest owners fail to comply with AER orders, the AER can take any steps it considers necessary and recover the costs from the licensee or working interest owners. ${ }^{215}$

Section 22 of the $C C A^{216}$ provides that the performance of an operation in accordance with a permit or licence under the CCA does not relieve a person from the requirements or liabilities arising under any other Act or otherwise. ${ }^{217}$ The same rule applies to approval holders for an in situ coal scheme. ${ }^{218}$ Similar to the OGCA, the CCA assigns continued liability to the approval holder of an in situ coal scheme to suspend or abandon the scheme notwithstanding the cancellation or suspension of the approval. ${ }^{219}$ The holder of an approval for an in situ coal scheme cannot agree to transfer its obligations with respect to suspension and abandonment of the scheme or its obligations to comply with the regulations, nor can it agree to transfer any requirements and directions of the AER or relieve itself by agreement of any costs and expenses arising from suspension and abandonment. ${ }^{220}$

Supra note 144.

Ibid, s 17(3):

Where a licence is suspended or cancelled pursuant to subsection (2),

(a) all rights conveyed by the licence are similarly cancelled or suspended, and

(b) notwithstanding the cancellation or suspension of the licence, the liability of the licensee to abandon the facility and reclaim the facility site or suspend operations as the Section 29: Regulator directs continues after the cancellation or suspension.

Abandonment of a well or facility does not relieve the licensee, approval holder or working interest participant from responsibility for the control or further abandonment of the well or facility or from the responsibility for the costs of doing that work.

The Orphan well provisions in the OGCA do not apply to UCG wells. The CCR, supra note 186, when updated, will stipulate that the AER will require a letter of credit in the amount it will take to abandon the in situ coal scheme. Information provided by the AER (former ERCB), email from 24 September 2012, (on file with author).

Ibid, ss 100(3), 104(3), 105(4).

CCA, supra note 143 .

Ibid, s 22.

Ibid, s 31.7.

Ibid, s 30(3).

Ibid, s 31.5. 
Further, the $S R A^{221}$ provides statutory cause of action to owners and occupiers who suffer damage as a result of oil and gas and other operations on their lands. ${ }^{222}$ Compensation under section 30 SRA includes the following: (1) damages to land of the owner or occupant off the area granted; (2) damages to livestock or other personal property; or (3) time spent or expense incurred by the owner or occupant to recover strayed livestock. ${ }^{223}$

Other claims will have to be based on tort law.

\section{TORT LIABILITY}

Tort actions under the common law include trespass, nuisance, negligence, and strict liability. The following section will briefly provide an overview of each and canvass case law that may be indicative for future UCG related cases.

\section{a. Trespass}

Trespass to land could be relevant for UCG activities, for example, if the UCG operation results in damage to an adjacent oil and natural gas reservoir or if the operator did not obtain prior consent to access the surface land. Trespass to land arises from "an intended but unjustifiable interference with another person's possession of land.... [I]nterference with the legal right of possession is sufficient." ${ }^{224}$ To constitute trespass, the defendant must in some direct way interfere with the land possessed by the plaintiff. ${ }^{225}$ " The requirement of directness differentiates trespass from nuisance, which is committed when the defendant [in a UCG operation: the project applicant or UCG operator] makes a use of his land that indirectly affects the land of the plaintiff." ${ }^{226}$ Trespass to land is not limited to a single act but can be a continuous act. ${ }^{227}$ Repeated acts of trespass will give rise to a continuing cause of action. ${ }^{228}$ Trespass requires only interference with possession; the plaintiff does not have to establish that harm occurred. ${ }^{229}$

\section{b. Nuisance}

Nuisance claims against the UCG operator could arise if the UCG activities affect an adjacent oil and natural gas reservoir or water wells, cause groundwater contamination or subsidence thus affecting another person's interests, for example, an owner of mineral rights or a landowner. The tort of private nuisance ${ }^{230}$ can arise when there is "an unreasonable

\footnotetext{
$221 \quad$ Supra note 152.

222 Sarah Nykolaishen \& Nigel Bankes, "The Jurisdiction of the Alberta Surface Rights Board under Section 30 of the Surface Rights Act” (2011) 49:1 Alta L Rev 1.

223 Supra note 152, ss 25(5), 30(1).

224 Alastair R Lucas, William A Tilleman \& Elaine L Hughes, Environmental Law and Policy, 3d ed (Toronto: Emond Montgomery Publications, 2003) at 108; see also Burnaby (City of) v. Thandi, 2005 BCSC 1478, 14 MPLR (4th) 59.

225 Gerald Henry Louis Fridman, The Law of Torts in Canada, 3d ed (Toronto: Carswell, 2010) at 29.

226 Ibid at 29.

$227 \quad$ Ibid at 32.

$228 \quad$ Ibid at 32

229

Paul Muldoon et al, An Introduction to Environmental Law and Policy in Canada (Toronto: Emond Montgomery Publication Limited, 2009) at 192.

230 In addition, litigation can be initiated for a public nuisance in Canada "to protect the public interest from damage to health, safety, mortality, comfort or convenience” (Hughes, Lucas \& Tilleman, supra note 224 at 100).
} 
interference with the use and enjoyment of land that is owned and occupied by another person."231 Reasonableness is determined depending on the circumstances, such as the gravity of the harm and the nature of the neighbourhood. ${ }^{232}$ The Supreme Court of Canada applied the following test for nuisance:

\begin{abstract}
The courts attempt to circumscribe the ambit of nuisance by looking to the nature of the locality in question and asking whether the ordinary and reasonable resident of that locality would view the disturbance as a substantial interference with the enjoyment of land. Among the criteria employed by the courts in delimiting the ambit of the tort of nuisance are considerations based on the severity of the harm, the character of the neighbourhood, the utility of the defendant's conduct, and the question whether the plaintiff displayed abnormal sensitivity. ${ }^{233}$
\end{abstract}

For UCG activities site location is crucial. Careful site selection has the potential to diminish interference with other interests.

\title{
c. Negligence
}

Negligent site selection or the negligent carrying out of UCG operations could result in all sorts of damage. Of particular risk is damage in the form of water contamination or subsidence as the past history of UCG trials has shown. ${ }^{234}$ If UCG operations are conducted in a careless manner and result in damage, liability for negligence can arise for losses due to "conduct falling below the standard established for the protection of others against unreasonable risk of harm.”"235 Under negligence the plaintiff has to establish:

(1) Duty of care. The defendant had an obligation to the plaintiff to act reasonably;

(2) Standard of care. The defendant did not act reasonably in the circumstances;

(3) Causation. The plaintiff would not have suffered harm if not for the defendant's conduct; and

(4) Forseeability. The harm suffered by the plaintiff was a foreseeable consequence of the defendant's breach of the standard of care. ${ }^{236}$

There is no specific case law applying to UCG activities. But other case law with respect to, for example, exploration of hydrocarbons and the contamination of the soil, clarifies the

Hughes, Lucas \& Tilleman, ibid at 9. See Mandrake Management Consultants Ltd v Toronto Transit Commission (1993), 11 CELR (NS) 100 (ONCA); Fridman, supra note 225 at 147-93.

Muldoon, supra note 229 at 191.

See the recent case of a UCG project causing groundwater contamination in Queensland, Australia: Queensland Government, "Cougar Energy UCG Incident - Update,” online: <http://www.south burnett.biz/pdfs/UCQQA2.pdf>; “Cougar Energy shares down on UCG Ban,” (8 July 2011), online: 9 News Finance $<$ http://www.finance.ninemsn.com.au/newsbusiness/aap/8270821/cougar-energy-sharesdown-on-ucg-ban>. 
duty of care. For example in Restaurant Lepoirier Ltée v. Foulem ${ }^{237}$ the Court held that the defendant was liable in negligence to a land owner whose premises were located across the street from the defendant for soil and air contamination from hydrocarbons that escaped from the defendant's service station. Likewise, in Bennett v. Imperial Oil Ltd., ${ }^{238}$ the Newfoundland Supreme Court ruled that the defendant oil company was liable in negligence to a neighbouring land owner for water contamination caused by gasoline that leaked from a storage tank.

\section{d. Strict Liability}

There may also be strict liability for damage from UCG activities under the famous decision of Rylands v. Fletcher ${ }^{239}$ regarding non-natural use of land. A basic principle derived from Rylands is that a defendant who chooses to engage in a dangerous activity assumes responsibility for the damage that occurs from that activity: "We think that the true rule of law is, that the person who for his own purposes brings on his lands, and collect and keeps there anything likely to do mischief if it escapes, must keep it in at his peril, and if he does not do so, is prima facie answerable for all the damage which is the natural consequences of its escape." 240 The Supreme Court of Canada has stated that "[i]t is not every use to which land is put that brings into play that principle. It must be some special use bringing with it increased danger to others, and must not merely be the ordinary use of the land or such a use as is proper for the general benefit of the community."241 This extended rule of Rylands is flexible in that sense that the circumstances of the time and place of dispute and the current practice of mankind will influence what is considered dangerous or non-natural use. With respect to UCG activities in particular, the risk of groundwater contamination and subsidence could establish a case for strict liability.

In R. v. Petro-Canada, ${ }^{242}$ the Ontario Court of Appeal ruled that the defendant oil and gas company was liable under the doctrine of strict liability for damage arising from a pipeline failure. Similarly, the Supreme Court of British Columbia in BC Telephone Co. v. Shell Canada Ltd. ${ }^{243}$ held that the defendant oil company was strictly liable for damage to subsurface cables and conduits caused by a gasoline tank leak on the defendant's property.

\section{e. Summary}

UCG activities, as all other activities, entail risks of damage. Risks of groundwater contamination and subsidence first come to mind when assessing potential liability claims. Liability claims arising from UCG activities can be based on statutes. UCG operators will be liable for reclamation and abandonment as set out in the OGCA, CCA, and SRA. Other liability claims must be based on tort law. There is no specific case law with respect to UCG activities. However, the precedents above indicate that tort liability from UCG activities can 
arise under trespass, nuisance, negligence, and strict liability. Furthermore, liability for the contravention of environmental protection statutes can arise in addition to tort liability under the common law. ${ }^{244}$

\section{F. RECOMMENDATIONS}

Alberta undertook a remarkable step in 2011 when it put into place a regulatory regime that specifically addressed UCG operations - an emerging clean coal technology. There are only a few jurisdictions that have addressed UCG specifically and of those few even fewer have a regime in place that comprehensively regulates the currently known issues of UCG. ${ }^{245}$ Most jurisdictions are at the stage of acknowledging UCG as a viable and emerging technology and thus are only begining to draft and implement a legal and regulatory framework for UCG. ${ }^{246}$ The ERCB (now AER) reviewed other jurisdictions and their attempts to address UCG and finally decided to develop and adopt its own UCG regime. In general, at this early stage in the new regime, it is difficult to suggest improvements because the existing regime will prove its feasibility as soon as the first commercial projects are launched.

With growing experience of UCG activities, the regulatory framework will likely have to be adapted in light of that new knowledge. Further, the AER is currently in the process of drafting and amending regulations with respect to UCG. This article argues that Alberta has taken a first and very important step in addressing UCG activities and preparing for future project applications. Alberta's UCG regime is an elaborate regime that minimizes the risk of potential conflicts with other mineral rights owners by requiring a UCG operator to own all natural resources such as oil, gas, and coal in order to obtain a UCG approval. ${ }^{247}$

Alberta's regulatory framework for UCG activities is based upon long experience with other natural resources extraction and development, especially oil, gas, and coal activities. The regulatory framework for UCG projects draws upon scientific and technological development and practical experience. The CCA allows the AER to refine and update its rules and regulations as UCG technologies are better assessed with growing experience. The inclusion of untried and unproven UCG technology in Part 6 of the CCA provides flexibility for future technological development in UCG, which is advantageous for the operators and the regulator, the AER. However, the regulatory framework should provide more clarity with respect to environmental impact assessments. As pointed out, UCG operators are not currently required to carry out a mandatory environmental impact assessment although an

For potential liability resulting from environmental impacts of CCS projects under the EPEA, supra note 165, see Allan Ingelson, Anne Kleffner \& Norma Nielson, "Long-Term Liability for Carbon Capture and Storage in Depleted North American Oil and Gas Reservoirs - A Comparative Analysis" (2010) 31 Energy LJ 431 at $452-54$.

245 See e.g. Neil Scott, "Underground Coal Gasification and Coal Bed Methane the Challenge of Resource and Tenement Competition" (Paper delivered at the Underground Coal Gasification Association Annual Conference, 2-3 May 2012) at 7, online: Scott Law <http://www.scottlaw.com.au/assets/down loads/Item\%205\%20UCG\%20 \&\%20CBM\%20Resource\%20and\%20Tenement\%20Competition.pdf>. South Africa currently plans to develop a UCG gas infrastructure framework in 2013. See Martin Creamer, "World recognizing UCG as viable - clean coal analyst”(26 April 2013), online: Mining Weekly <http://www.miningweekly.com/article/world-recognising-underground-coal-gasification-asviable-clean-coal-analyst-2013-04-26>.

247 In Queensland and the US tenement competition between coalbed methane and coal mining is an issue. This is also anticipated for CBM and UCG (Scott, supra note 245). 
UCG project operator may be required to prepare an EIA on a case by case decision. Here, it is argued that EIA should be mandatory for UCG activities. UCG is a new technology which involves environmental risks. The history of UCG trials showed that UCG activities resulted in damage to the environment, especially ground water contamination and subsidence. The United Kingdom established mandatory EIAs for UCG activities in order to consider groundwater and general environmental factors during the site selection and site investigation stage. ${ }^{248}$ Also, endorsing the listing UCG activities as a mandatory activity under the Environmental Assessment Regulation ${ }^{249}$ will provide for certainty for the project proponent or operator as well.

\section{CONCLUSION}

UCG is an emergent and promising technology for countries with deep coal reserves. Currently, many countries with coal reserves are doing research on UCG and striving for future commercial application and deployment. As with all types of energy, UCG also has disadvantages, such as possible impacts on fresh water aquifers and subsidence. The advantages of UCG include the opportunity to reach very deep and otherwise unminable coal. UCG reduces pollutants which partly remain in the underground cavity or can be separated from the syngas before combustion. UCG reduces $\mathrm{CO}_{2}$ emissions if it is operated in conjunction with a combined cycle power plant and the $\mathrm{CO}_{2}$ is separated and stored in suitable geological formations that are frequently found in close proximity to the UCG coal seam, including the already converted coal seam. ${ }^{250}$ So far, Alberta, spurred on by two concrete demonstration project applications, has shaped a regulatory framework for UCG. The regulatory framework is built upon similar systems that apply to oil and gas and oil sands activities. The design is promising for the industry and the regulator because it allows for alterations and improvements with growing knowledge and experience that is beneficial for all participants. There are no signs that the recent creation of the AER will change any policy direction for UCG activities.

However, in light of the deferred Swan Hills project, it appears that irrespective of the advantages of UCG as an alternative energy source, current economics, especially low natural gas prices, will limit the deployment of UCG technology. 